\title{
Output Indicators of Audit Quality: A Framework Based on Literature Review
}

\author{
Amine El Badlaoui", Mariam Cherqaoui, Omar Taouab \\ National School of Business and Management of Kenitra, Ibn Tofail University, Kenitra, Morocco
}

Received August 22, 2021; Revised October 15, 2021; Accepted November 11, 2021

\section{Cite This Paper in the following Citation Styles}

(a): [1] Amine El Badlaoui, Mariam Cherqaoui, Omar Taouab , "Output Indicators of Audit Quality: A Framework Based on Literature Review," Universal Journal of Accounting and Finance, Vol. 9, No. 6, pp. 1405-1421, 2021. DOI: 10.13189/ujaf.2021.090619.

(b): Amine El Badlaoui, Mariam Cherqaoui, Omar Taouab (2021). Output Indicators of Audit Quality: A Framework Based on Literature Review. Universal Journal of Accounting and Finance, 9(6), 1405-1421. DOI: 10.13189/ujaf.2021.090619.

Copyright $\odot 2021$ by authors, all rights reserved. Authors agree that this article remains permanently open access under the terms of the Creative Commons Attribution License 4.0 International License

\begin{abstract}
The purpose of this paper is to review the research literature dealing with output indicators that indicate the level of audit quality: Auditor's report, bankruptcy, client satisfaction, auditor litigation and expectation-gap. This paper reviews a total of 89 papers authored post-2012, which relates to output indicators of audit quality, using a Systematic Literature Review. For each study, we demonstrated the methodology used (Archival/ Experimental), the sample chosen and the main results. Based on our findings, studies on the audit report state that it should contain more information and detail. For bankruptcy, researchers find that going concern opinion is an essential element in predicting bankruptcy, and that the auditor becomes more conservative after a bankruptcy. Through experimental studies on client-satisfaction studies, researchers have ruled on the elements that can satisfy clients on the audit work. The research on auditor litigation state that auditors being sued provide higher audit quality because they have more wealth at risk in case of litigation. The common cause of audit expectation-gap is the misperception of the auditors' responsibility to detect and prevent fraud. We contribute to the literature in the following aspects. First, we propose an audit quality framework that includes all the factors indicating the level of the external audit's quality (Auditor-related indicators; Audit-process indicators; Output indicators). Second, we present a review on the output indicators of audit quality (auditor's report, bankruptcy, client satisfaction, auditor litigation and expectation-gap). Thirdly, we draw on the results of
\end{abstract}

previous literature and provide suggestions for future research.

Keywords Audit Quality, Auditor's Report, Bankruptcy, Client Satisfaction, Auditor Litigation, Audit Expectation-Gap

\section{Introduction}

By virtue of its functions, audit is qualified as a governance mechanism; its role lies in improving the financial communication of organizations, ensuring good external governance and improving the confidence of third parties in the organization. Its power and importance in decision-making arouse the interest of right holders (citizens, employees, shareholders, etc.) who need to be assured of its quality.

However, measuring this quality is not an easy task, because the audit engagement process varies from one engagement to another depending on its context, especially since the content and focus of the audit report are so standardized that they offer little opportunity for differentiation. In this sense, it is only in the event of a bankruptcy or financial scandal (Xerox, 2000; Enron, 2001 and WorldCom, 2002) that we can focus on the failure of the audit mission.

To this end, the researchers began to discuss the audit quality, and more specifically, indicators for measuring it. 
Several initiatives of measurement of the audit quality have been conducted by regulatory bodies of the audit profession $[1,2,3]$ and researchers $[4,5,6]$, whose objective is to determine the most effective way to assess and determine audit quality.

In 2014, the International Auditing and Assurance Standards Board (IAASB) has developed an audit quality framework comprising five key elements: Inputs; Process; Outputs; Key interactions between the stakeholders within the financial reporting supply chain; and Context Factors. One year later, the Public Company Accounting Oversight Board (PCAOB) developed audit quality framework including 28 potential audit quality indicators divided into three groups: Audit professionals; the audit process; and the audit results. Francis' [5] typology distinguishes six categories of research related to the measurement of audit quality. The aim is to focus on inputs that influence the quality, process, firm and market of the audit, institutions and their regulations as well as the economic consequences of audit outputs. Based on the document published by the IAASB, Chihi [7] proposes a taxonomy of research on audit quality using two approaches: direct (audit process) and indirect (inputs and outputs) approach.

Due to the differences in audit quality frameworks and the plurality of audit quality measurement indicators, we conduct a comprehensive review of audit quality studies to provide a framework which explores the determinants of external audit quality currently used in research and interpreting their results.

We contribute to the literature in the following aspects. First of all, we propose an audit quality framework that includes all the factors indicating the level of the external audit's quality (Auditor-related indicators; Audit-process indicators; Output indicators). Second, we present a systematic literature review on the output indicators of audit quality (auditor's report, bankruptcy, client satisfaction, auditor litigation and expectation-gap). For each audit quality indicator, we provide a summary of the methodological approaches used (Archival/Experimental) and the main findings. Thirdly, we draw on the results of previous literature and provide suggestions for future research of both academics and regulatory institutions.

The remainder of the article is organized as follows. First, we discuss different definitions of audit quality that are available in different audit literatures. Section 2 discusses the methodology used to collect and analyze research related to the outputs indicators of audit quality. Section 3 reviews and summarizes the literature and publications dealing with outputs indicators of audit quality.

\section{Defining Audit Quality}

Since Deangelo's first attempt at a definition, no definition has led to universal recognition. Indeed, audit quality is a complex concept with several indicators $[2,5,8]$. Practitioners can define audit quality by reference to applicable audit standards and by the veracity and fairness of financial statements to users. However, the accounting literature links audit quality to several measurement variables.

DeAngelo [4] defined audit quality by combining two important aspects: competence and independence. By reporting the definition as cited by Deangelo: audit quality is "the market-assessed joint probability that a given auditor will both discover a breach in the client's accounting system and report the breach".

This definition was later criticized by several researchers. To Knechel et al. [6], the definition has not been reconciled with the audit risk model and the perception of market participants can be erroneous. DeFond and Zhang [9] argue that this definition has redefined the auditor's role to the simple detection and notification of mechanical violations of generally accepted accounting principles (GAAP).

The table 1 below illustrates the most recognized definitions of audit quality. 
Table 1. Definitions of audit quality

\begin{tabular}{|c|c|c|}
\hline Categories & Definition & Reference \\
\hline \multirow{5}{*}{$\begin{array}{l}\text { Practitioner } \\
\text { literature }\end{array}$} & $\begin{array}{l}\text { The term audit quality encompasses the key elements that create an environment which maximizes the } \\
\text { likelihood that quality audits are performed on a consistent basis. }\end{array}$ & {$[2]$} \\
\hline & $\begin{array}{l}\text { Meeting investors' needs for independent and reliable audits and robust audit committee communications } \\
\text { on: (1) Financial statements, including related disclosures; (2) Assurance about internal control; and (3) } \\
\text { Going concern warnings. }\end{array}$ & [3] \\
\hline & A professional service delivered by experts in response to economic and regulatory demand. & [6] \\
\hline & $\begin{array}{l}\text { An audit involves the directors of a company, engaging auditors to report in a way prescribed by } \\
\text { legislation (a true and fair view opinion) to the users. }\end{array}$ & [8] \\
\hline & $\begin{array}{l}\text { Audit quality is one performed "in accordance with generally accepted auditing standards (GAAS) to } \\
\text { provide reasonable assurance that the audited financial statements and related disclosures are (1) } \\
\text { presented in accordance with GAAP and (2) are not materially misstated whether due to errors or fraud." }\end{array}$ & [11] \\
\hline \multirow{5}{*}{$\begin{array}{l}\text { Accounting } \\
\text { literature }\end{array}$} & $\begin{array}{l}\text { Higher audit quality is "greater assurance that the financial statements faithfully reflect the firm's } \\
\text { underlying economics, conditioned on its financial reporting system and innate characteristics." }\end{array}$ & [9] \\
\hline & Audit quality is the probability financial statements containing no material omissions or misstatements. & {$[10]$} \\
\hline & $\begin{array}{l}\text { Audit quality describes how well an audit detects and reports material misstatements of financial } \\
\text { statements, reduces information asymmetry between management and stockholders and therefore helps } \\
\text { protect the interests of stockholders. }\end{array}$ & [12] \\
\hline & $\begin{array}{l}\text { Audit quality is how well an audit process detects and reports material misstatements in the financial } \\
\text { statements. }\end{array}$ & [13] \\
\hline & $\begin{array}{l}\text { A level of confirmation between the value an audit creates and the expectations to audit of third-party } \\
\text { users and audit clients. }\end{array}$ & [14] \\
\hline
\end{tabular}

In summary, audit quality has been a topic of significant interest in scientific research. In order to improve the understanding of audit quality, numerous studies have tried to detect the association between audit quality and other variables. However, since audit quality is difficult to observe, studies have operationalized it in different ways. From the above, we can conclude that "Audit quality is an audit mission performed by a competent, independent, and experienced professional, in accordance with generally accepted auditing standards, to provide financial statements' users with reasonable assurance, in the auditor's report, that the financial statements and related information are presented in accordance with auditing standards and are not materially misstated."

\section{Methodology}

In order to identify papers dealing with output indicators of audit quality, we adopt a systematic literature review (SLR) based on the guidelines presented by Kitchenham et al. [15].

In contrast to an ad hoc literature review, an SLR is a methodologically rigorous review of research results that identify, evaluate and interpret the available empirical studies conducted on a topic, research question, or a phenomenon of interest [16].

The steps proposed by Kitchenham [16] and Kitchenham et al. [15] include three main stages: Planning the review, Conducting the review and Reporting on the review.

In the stage of "planning the review", researchers identify the need for a review, specify research questions, and develop a review protocol. When conducting the review, they identify the research, select the primary studies, assess the quality of the studies, extract, analyze, and synthesize data. When reporting the review, the researchers write the report to disseminate their findings from the literature review [17].

This section describes the steps of the methodology used to perform the systematic review conducted in this study.

\section{Planning the review}

The issue of measuring audit quality has been studied over a long period of time in numerous documents. This stream of research has been based largely on the question of what drivers indicate the level of audit quality.

Several initiatives of measurement of audit quality have been conducted by regulatory bodies of the audit profession [1,2,3] and researchers [4,5,6], whose objective is to determine the most effective way to assess and determine audit quality.

Following the main objective of our research work, the research questions can be formulated as follows:

Research Question $\mathbf{n}^{\circ}$ 1: How can we conceptualize taxonomy for the output indicators of audit quality (Auditor's report, bankruptcy, client satisfaction, auditor litigation and expectation-gap)?

Research Question n'2: What is the result deduced from the overall research on outputs indicators of audit quality?

\section{Conducting the review}

The search process was conducted between early January and late April 2020 and was based on the search 
engine "Google Scholar (GS)" which allows displaying all papers published on all scientific databases. The search process was limited to the search for relevant articles and papers published post-2012 by researchers and international regulatory bodies, aimed at investigating the link between output indicators and the external audit quality. The sets of criteria to determine papers to be included are:

1. Recent work addressing output indicators of the audit quality;

2. Articles published between 2013 and April 2020;

3. Articles published in specialized journals and/or conference;

4. Articles that contain the keywords in the title, the abstract or full text;

5. Relevant documents issued by international regulatory bodies.

Fig. 1 shows the study selection process adopted in this paper using Kitchenham's [16] guidelines.

The first stage involved using the following search query: "Audit Quality" and "Auditor's Report" or "Bankruptcy" or "Client Satisfaction" or "Auditor Litigation" or "Audit Expectation-Gap".

As a result of the first stage, 3,950 primary studies were identified.

In the first iteration, the papers identified in the first stage were examined while in the second iteration the references contained in remaining papers in stage 3 were examined. Subsequently, stages 3 and 4 were undertaken twice.

\section{Reporting on the review}

The data extraction and synthesis step consisted of extracting the data to be used in the analysis step. Three types of data were extracted from remaining papers:

1. Study reference: Authors, year of publication and the country;

2. Methodological elements adopted: Archival or experimental;

3. Principle results of the study.
The verification and analysis of the content of the selected articles followed a logic based on several iterations, depending on the need for our analysis.

On average, each article was rechecked more than three times; In case of anomaly, the modification of our results is immediately taken into account and synthesized in our main table. The data for each article was extracted manually and entered into Microsoft Excel, which allowed us to perform the descriptive analysis.

Table 2 provides the number of papers excluded in each iterational stage.

The first iteration consists of selecting papers that answer our research questions based on the keywords entered in the "Google Scholar" database. At the first stage, 3,950 papers have been identified and we have undertaken stages 2 to 4 .

The number of papers excluded based on their titles (stage 2) is 3,154 because Google Scholar's search results are sorted by relevance, so the last few pages of results contain off-topic articles with keywords that appear only a few times in the body of the text or in the references used by the researchers. At this stage, we have excluded papers whose titles clearly state that the objective and the research question addressed do not fall within our field of study.

Several titles of the articles remain vague and do not show the overall purpose of the research, and therefore a reading of the abstracts allowed us to exclude an article. So, at stage 3, we exclude 493 papers.

At stage 4, we exclude 245 papers whose full text does not include the research elements for our study or missing data.

The second iteration is based on the selection of papers from the references of the remaining papers at stage 3 and whose titles meet our selection's criteria of papers. So at stage 5 , the number of papers selected is 1,227 , and we excluded repeated articles, in stage 6 , due to their consideration in the first iteration, and we undertook steps 3 and 4. Overall, the systematic review resulted in the identification of 89 relevant papers (58 from the first iteration and 31 in the second one).

Table 2. Number of papers excluded in each iteration and stage.

\begin{tabular}{|c|c|c|c|c|}
\hline Iteration & Primary papers & Stage of exclusion & $\mathrm{N}^{\circ}$ of papers excluded & $\begin{array}{c}\mathbf{N}^{\circ} \text { of papers } \\
\text { remaining }\end{array}$ \\
\hline \multirow{3}{*}{1} & \multirow{3}{*}{ Stage 1: 3,950} & Stage 2: Title & 3,154 & 796 \\
\hline & & Stage 3: Abstract & 493 & 303 \\
\hline & & Stage 4: Full text & 245 & 58 \\
\hline \multicolumn{4}{|c|}{ Number of papers remaining from the first iteration } & 58 \\
\hline \multirow{3}{*}{2} & \multirow{3}{*}{ Stage 5: 1,227} & Stage 6: Repeated papers & 845 & 382 \\
\hline & & Stage 3: Abstract & 254 & 128 \\
\hline & & Stage 4: Full text & 97 & 31 \\
\hline \multicolumn{4}{|c|}{ Number of papers remaining from the second iteration } & 31 \\
\hline \multicolumn{4}{|c|}{ Final number of papers } & 89 \\
\hline
\end{tabular}




\section{Results}

We organize our review around five outputs indicators of audit quality. The choice of these five indicators is based on a set of research $[1,5,7,9]$, that has classified the indicators of audit quality in great majority around 3 main parts: Auditor-related indicators; Audit-process indicators and Output indicators.

Following these research, we propose the following taxonomy:

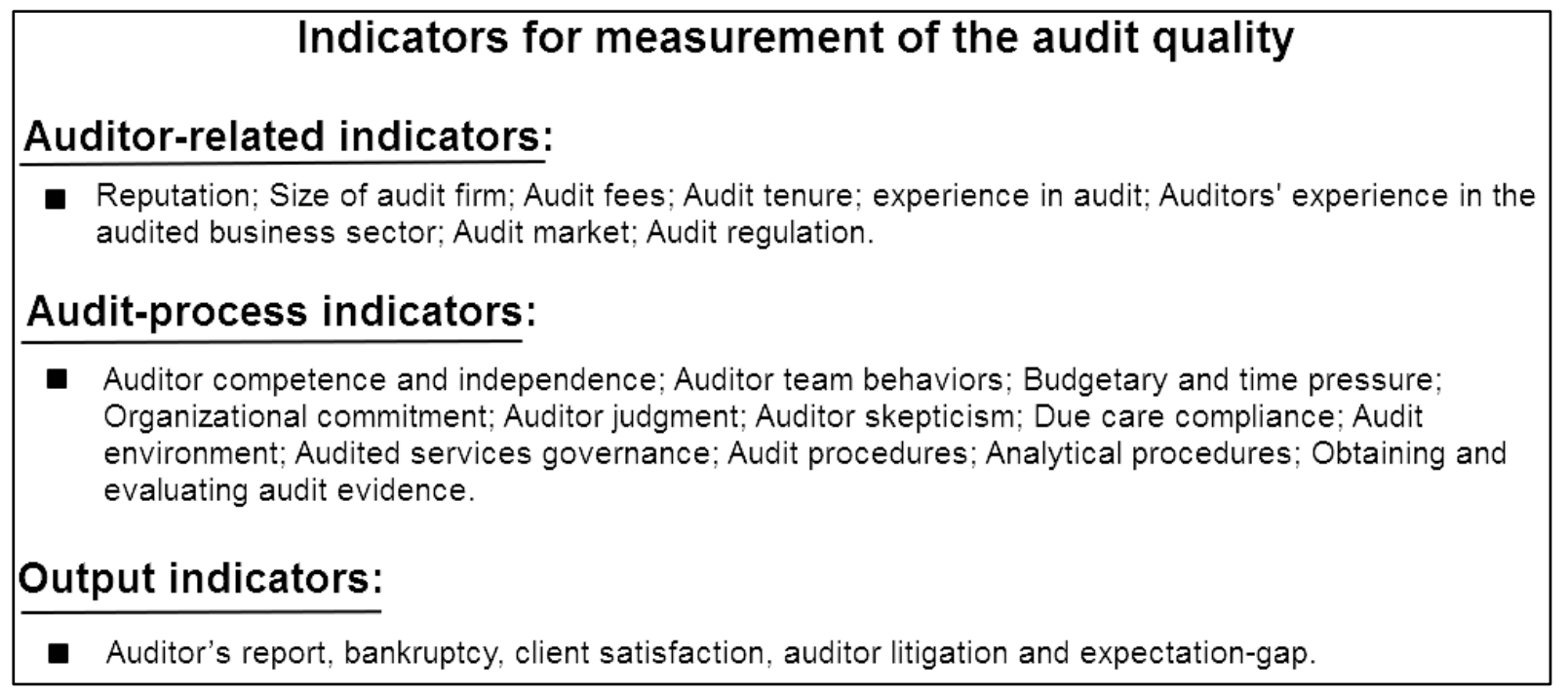

Figure 2. Audit Quality Framework

\section{- Audit Quality Attributes and Auditor's Report}

The audit report is the main deliverable that deals with the outcome of the audit process. Because of its nature as a legal document produced by an external and independent professional, it is a potential source of information for users.

The main question in the current debate on audit reporting is whether the standard audit report communicates the appropriate information to stakeholders and whether its form and content promote audit quality [18]. Also, whether there is a relationship between engagement partner disclosure and improved audit quality.

An audit report that clearly conveys the outcome of an audit is likely to positively influence audit quality [6].

Table 3. Audit Quality Attributes and auditor's report

\begin{tabular}{|c|c|c|l|}
\hline Reference & Method & Sample & \multicolumn{1}{|c|}{ Principle results } \\
\hline \multicolumn{5}{|c|}{ Audit partners } \\
\hline$[19]$ & Archival & 800 individual auditors / China & $\begin{array}{l}\text { Positive association between audit quality and specific audit } \\
\text { partners, marked by the conservatism of auditors who have a } \\
\text { western education or work for a Big N and the aggressiveness of } \\
\text { auditors with a master's degree or higher or who have a political } \\
\text { affiliation. }\end{array}$ \\
\hline$[20]$ & Archival & $\begin{array}{c}\text { Companies listed on the } \\
\text { London Stock Exchange / UK }\end{array}$ & $\begin{array}{l}\text { Positive relationship between improved audit quality and partner } \\
\text { engagement signature. }\end{array}$ \\
\hline$[21]$ & Archival & $\begin{array}{c}\text { More than 3900 client } \\
\text { fiscal-year observations / } \\
\text { Netherlands }\end{array}$ & $\begin{array}{l}\text { Insignificant relationship between the improvement of the audit } \\
\text { quality and audit partner signature. }\end{array}$ \\
\cline { 1 - 3 }$[22]$ & Experimental & $\begin{array}{r}19 \text { practicing audit partners / } \\
\text { Canada }\end{array}$ & $\begin{array}{l}\text { Positive relationship between disclosing engagement partners and } \\
\text { improving audit quality. }\end{array}$ \\
\hline
\end{tabular}


Table 3 Continued

\begin{tabular}{|c|c|c|c|}
\hline \multicolumn{4}{|c|}{ Key/Critical audit matters (KAM/CAM) } \\
\hline [24] & Experimental & $\begin{array}{l}165 \text { respondents to the report of } \\
\text { IAASB's } 2012 \text { Invitation to } \\
\text { Comment / Several countries }\end{array}$ & $\begin{array}{l}\text { Users support IAASB's proposals, including: KAM, Going concern, } \\
\text { Auditor's judgments and process and the disclosure of the } \\
\text { engagement partner's name. }\end{array}$ \\
\hline [25] & Experimental & $\begin{array}{c}\text { 141 Alumni from a public } \\
\text { business school / U.S }\end{array}$ & $\begin{array}{l}\text { CAM significantly impact investment decisions contrary to the } \\
\text { standard audit report or CAMs mentioned in the footnotes. }\end{array}$ \\
\hline [26] & Experimental & $\begin{array}{c}150 \text { non-professional investors / } \\
\text { U.S }\end{array}$ & $\begin{array}{c}\text { Despite their impact on reducing management's credibility, CAM do } \\
\text { not have an impact on investor's valuation judgments. }\end{array}$ \\
\hline [27] & Archival & $\begin{array}{l}\text { Post-2007 research / Several } \\
\text { countries }\end{array}$ & $\begin{array}{c}\text { While the audit report is useful for stakeholders, it should contain } \\
\text { more information about the entity and the audit, including } \\
\text { accounting policies, inherent risks, the audit process, and audit } \\
\text { judgments. }\end{array}$ \\
\hline [28] & Experimental & $\begin{array}{c}98 \text { students enrolled in a } \\
\text { graduate accounting degree / } \\
\text { Canada } \\
\end{array}$ & $\begin{array}{l}\text { The KAMs communicated in the audit report have an } \\
\text { attention-directing impact. }\end{array}$ \\
\hline [29] & Experimental & $\begin{array}{l}\text { Investment professionals and } \\
\text { non-professional investors / } \\
\text { Several countries }\end{array}$ & $\begin{array}{l}\text { KAM are not of interest to non-professional investors as opposed to } \\
\text { investment professionals. }\end{array}$ \\
\hline \multicolumn{4}{|c|}{ Impact of new audit report format } \\
\hline [30] & Experimental & $\begin{array}{l}61 \text { bankers, } 118 \text { preparers and } \\
123 \text { auditors / Netherlands }\end{array}$ & $\begin{array}{l}\text { The information sought by the sample studied mainly concerns: (1) } \\
\text { Audit process and (2) Disclosure of errors in the financial } \\
\text { statements. The format of the audit report is not material. }\end{array}$ \\
\hline [31] & Archival & $\begin{array}{l}40 \text { recent research papers from } \\
2007 \text { to mid-2015 / Several } \\
\text { countries }\end{array}$ & $\begin{array}{l}\text { The new audit report has a positive impact on the flow of } \\
\text { information to users. }\end{array}$ \\
\hline [32] & Archival & $\begin{array}{l}488 \text { companies listed in London } \\
\text { Stock Exchange / U.K }\end{array}$ & Negative impact of the expanded audit report on investor perception. \\
\hline [33] & Archival & $\begin{array}{l}\text { French audit reports issued from } \\
2002 \text { to } 2011 \text { / France }\end{array}$ & $\begin{array}{l}\text { Disclosure of evaluation justifications has an impact on investment } \\
\text { decisions beyond the first year. }\end{array}$ \\
\hline [34] & Archival & $\begin{array}{l}\text { London Stock Exchange } \\
\text { premium companies / U.K }\end{array}$ & $\begin{array}{c}\text { The change in regulation does not affect investor reaction to audit } \\
\text { reports or the audit quality. }\end{array}$ \\
\hline [35] & Archival & $\begin{array}{l}\text { All listed companies / New } \\
\text { Zealand } \\
\end{array}$ & $\begin{array}{l}\text { Positive relationship between the new audit reporting regime and } \\
\text { improved audit quality. }\end{array}$ \\
\hline [36] & Archival & $\begin{array}{l}\text { London Stock Exchange } \\
\text { premium companies / U.K }\end{array}$ & $\begin{array}{l}\text { The adoption of the new audit report has a significant impact on } \\
\text { improving the financial reporting quality. }\end{array}$ \\
\hline
\end{tabular}

The traditional model of the audit report has been the subject of discussion and debate, as shown in table 3 , due to concerns about its content and communicative value. The lack of transparency regarding the financial statements, the audit engagement and the auditor was a major concern. There is evidence that the audit report does not fully fulfil its role as a document containing information on the credibility of the financial statements and as a signal and confidence mechanism for the benefit of the market. We also note that research is conducted much more in developed countries and has resulted in a consensus on research findings.

As a result, significant recent changes to the model have been proposed and, in some cases, approved by audit standard setters $[37,38]$. These initiatives have suggested the following additions to the audit report:

1. Audit engagement partners' names;

2. Statement of the auditor's independence;

3. Basis for the audit opinion

4. Critical / Key Audit Matters;

5. Auditor Commentary on Going Concern.
Following the adoption of these standards, several studies have looked at the effect of introducing the new audit report, and find mixed results. One stream of research claims that the adoption of the new standardized audit report provides informational value for stakeholders $[31,35,36]$, while another stream of research found a slightly positive or even zero impact [32].

In sum, research addressing the relationship between audit quality and the audit report appreciates the efforts made in recent years, while not ignoring the fact that several initiatives need to be undertaken to improve the informational value of the audit report.

\section{- Audit Quality Attributes and Bankruptcy.}

Bankruptcy represents the negative end of audit quality. For this reason, several studies have focused on the elements of bankruptcy prediction through the information contained in the audit report. While others have looked at consequences of bankruptcy on reputation when an unqualified opinion is issued just before bankruptcy. 
Table 4. Audit Quality Attributes and bankruptcy

\begin{tabular}{|c|c|c|c|}
\hline Reference & Method & Sample & Principle results \\
\hline \multicolumn{4}{|c|}{ Impact of bankruptcy on the behavior and type of auditor's opinions } \\
\hline [39] & Archival & $\begin{array}{l}93 \text { companies that had } \\
\text { received first-time GCMOs } \\
\text { / Sweden }\end{array}$ & $\begin{array}{l}\text { Positive relationship between bankruptcy of the client and the issuance } \\
\text { of a going concern modification opinions for the first time, whether by a } \\
\text { Big N or not. }\end{array}$ \\
\hline [40] & Archival & $\begin{array}{l}25 \text { failed and } 25 \text { non-failed } \\
\text { / New Zealand }\end{array}$ & $\begin{array}{l}\text { Positive but low significant relationship between audit opinion and } \\
\text { bankruptcy. }\end{array}$ \\
\hline [41] & Archival & $\begin{array}{c}823 \text { US and } 127 \text { UK } \\
\text { first-time GCOs / U.S. and } \\
\text { U.K } \\
\end{array}$ & $\begin{array}{l}\text { Investors who are in a creditor-friendly bankruptcy regime react more } \\
\text { negatively to a going concern opinion. }\end{array}$ \\
\hline$[42]$ & Archival & $\begin{array}{l}404 \text { private firms under } \\
\text { financial distress and } 404 \\
\text { not / Spain }\end{array}$ & $\begin{array}{l}\text { Auditor report has an informative value that helps to avoid a situation of } \\
\text { financial distress. }\end{array}$ \\
\hline [43] & Archival & $\begin{array}{l}5146 \text { non-financial firms / } \\
\text { U.S }\end{array}$ & $\begin{array}{l}\text { In the case of a probability of around } 8 \% \text { or more that the client is } \\
\text { bankrupt, an auditor's opinion on going concern must be issued. }\end{array}$ \\
\hline [44] & Archival & $\begin{array}{l}897 \text { new going concern } \\
\text { modification disclosures / } \\
\text { U.S }\end{array}$ & $\begin{array}{l}\text { To anticipate bankruptcy, investors refer to earnings announcements } \\
\text { rather than the presence of a going concern modification. }\end{array}$ \\
\hline [45] & Archival & $\begin{array}{l}340 \text { public companies that } \\
\text { filed for bankruptcy / U.S }\end{array}$ & $\begin{array}{l}\text { After the Great Recession, auditors are issuing going concern notices } \\
\text { before clients go bankrupt. }\end{array}$ \\
\hline \multicolumn{4}{|c|}{ Elements predicting bankruptcy } \\
\hline [46] & Archival & $\begin{array}{l}42 \text { listed financial } \\
\text { companies / U.S }\end{array}$ & $\begin{array}{l}\text { Low effect of going concern opinions in predicting bankruptcy. Auditors } \\
\text { are more interested in information other than financial and economic } \\
\text { ratios when forming their opinions. }\end{array}$ \\
\hline [47] & Archival & $\begin{array}{l}404 \text { companies in } \\
\text { bankruptcy / Spain }\end{array}$ & $\begin{array}{l}\text { The audit reports of bankrupt firm vary according to the following } \\
\text { elements: (1) auditor size, (2) client industry, (3) financial condition and } \\
\text { (4) the stage of insolvency legal proceedings. }\end{array}$ \\
\hline [48] & Archival & $\begin{array}{l}27189 \text { firm-year } \\
\text { observations / U.S }\end{array}$ & $\begin{array}{l}\text { Going concern opinions have a significant effect on the prediction of } \\
\text { bankruptcy, especially when they are included in a statistical model that } \\
\text { also incorporates financial ratios and market variables. }\end{array}$ \\
\hline [49] & Archival & $\begin{array}{c}1201 \text { bankruptcies and } \\
12589 \text { GCOs / U.S }\end{array}$ & $\begin{array}{l}\text { A going concern opinion leads to a probability of bankruptcy especially } \\
\text { for large companies and Big N clients. }\end{array}$ \\
\hline$[50]$ & Archival & $\begin{array}{l}69 \text { companies listed on the } \\
\text { BSE / Romania }\end{array}$ & $\begin{array}{l}\text { The existence of an audit committee does not play a role in preventing a } \\
\text { firm from going bankrupt. }\end{array}$ \\
\hline [51] & Archival & $\begin{array}{c}98 \text { failed and } 269 \\
\text { non-failed firms / U.K }\end{array}$ & $\begin{array}{l}\text { Positive relationship between the independence of the audit committee } \\
\text { and the prediction of the firm's insolvency. }\end{array}$ \\
\hline$[52]$ & Archival & $\begin{array}{l}\text { 70,959 company-year } \\
\text { observations / U.S }\end{array}$ & $\begin{array}{l}\text { The auditor's attributes are essential factors in predicting bankruptcy, } \\
\text { especially when the auditor is an industry expert, belongs to a large firm, } \\
\text { and has a long tenure. }\end{array}$ \\
\hline$[53]$ & Archival & 516 bankruptcies / U.S & $\begin{array}{l}\text { The probability of bankruptcy is low after a clean audit opinion. Also, } \\
\text { auditors who have committed a type II GCO error do not suffer any } \\
\text { negative effects. }\end{array}$ \\
\hline$[54]$ & Archival & $\begin{array}{l}404 \text { bankrupt and } 404 \\
\text { non-bankrupt firms / Spain }\end{array}$ & $\begin{array}{l}\text { In order to know whether a company is going to fail, any interested party } \\
\text { can simply rely on the audit report, and more specifically the type of } \\
\text { audit opinion and the comments that accompany it. }\end{array}$ \\
\hline$[55]$ & Archival & $\begin{array}{c}404 \text { bankrupt and } 404 \\
\text { non-bankrupt firms / Spain }\end{array}$ & $\begin{array}{l}\text { The audit report has an informative value and is a useful tool for } \\
\text { anticipating the occurrence of bankruptcies. }\end{array}$ \\
\hline$[56]$ & Archival & $\begin{array}{l}3139 \text { GC opinions relating } \\
\text { to } 508 \text { firms / Japan }\end{array}$ & $\begin{array}{l}\text { Positive relationship between a going concern announcement and an } \\
\text { increased probability of bankruptcy. }\end{array}$ \\
\hline$[57]$ & Archival & 2921 first-time GCOs / U.S & $\begin{array}{l}\text { Positive and lower significant relationship between the issuance of a } \\
\text { going concern opinion and bankruptcy. GCO varies according to the type } \\
\text { of auditor and the size of the auditee. }\end{array}$ \\
\hline
\end{tabular}

From table 4 above, we can divide research on the relationship between audit quality and bankruptcy into three blocks.

A stream of research studies the impact of bankruptcy on the behavior and type of auditor's opinions. They have found that the auditor becomes more conservative after bankruptcy and increasingly issues going concern modifications.
A stream of research that focuses on the elements that can predict bankruptcy, the most important of which is the auditors' opinion on going concern, which for the majority of researchers are the only indicator that provides information on the survival of firms [48, 57], while others have found no relationship between the issuance of a going concern opinion and the bankruptcy of a firm [44, 46]. 
Bankruptcy prediction models, on the other hand, have attracted the interest of researchers and have proposed several models. The first was proposed in the 1970s $[58,59]$ based on the analysis of traditional financial ratios. Subsequently, and with advances in technology, bankruptcy prediction models have evolved through the use of techniques such as data mining [60] and artificial intelligence [54].

\section{Audit Quality Attributes and Client Satisfaction}

Kotler [61] defined satisfaction as "Customers' feeling of pleasure/disappointment after comparing the perceived quality of a product with their expectations". With respect to audit quality, it is the clients' (auditees) perception of how well the audit team meets their expectations. By delivering high quality services to their clients, it will maximize client satisfaction.

Table 5. Audit Quality Attributes and Client Satisfaction.

\begin{tabular}{|c|c|c|c|}
\hline Reference & Method & Sample & Principle results \\
\hline [62] & Experimental & $\begin{array}{l}56 \text { respondents from head of } \\
\text { finance, head of internal audit and } \\
\text { staff / Indonesia }\end{array}$ & $\begin{array}{l}\text { A positive relationship between client satisfaction and (1) auditor's } \\
\text { prior experience, (2) industry expertise, (3) responsive to the } \\
\text { client's needs, (4) conduct of audit field work, (5) commitment to } \\
\text { quality, (6) exercised due care throughout the engagement and (7) } \\
\text { respect of high ethical standards. }\end{array}$ \\
\hline [63] & Experimental & $\begin{array}{l}70 \text { Audit firm's clients listed on the } \\
\text { Toronto Stock Exchange / Canada }\end{array}$ & $\begin{array}{l}\text { Positive relationship between client satisfaction and (1) audit firm's } \\
\text { service customization and (2) responsiveness. }\end{array}$ \\
\hline$[64]$ & Experimental & $\begin{array}{l}\text { Heads of safety programs within } \\
\text { Embakasi Constituency / Kenya }\end{array}$ & $\begin{array}{l}\text { Positive relationship between client satisfaction and standard } \\
\text { setting. While, there is a negative relationship between client } \\
\text { satisfaction and behavior modification. }\end{array}$ \\
\hline [65] & Experimental & $\begin{array}{c}1500 \text { non-profit organizations / } \\
\text { Belgium }\end{array}$ & $\begin{array}{l}\text { Clients are satisfied with the auditor's behavior more than } \\
\text { economic factors. }\end{array}$ \\
\hline$[66]$ & Experimental & $\begin{array}{l}204 \text { auditors at two public } \\
\text { accounting firms / U.S }\end{array}$ & $\begin{array}{l}\text { A stronger relationship between auditors and auditees leads to a } \\
\text { better audit service. }\end{array}$ \\
\hline [67] & Experimental & $\begin{array}{l}235 \text { finance professionals and } 35 \\
\text { council internal auditors / Australia }\end{array}$ & $\begin{array}{l}\text { Significant association between client satisfaction and (1) auditor } \\
\text { expertise and (2) responsiveness to client needs. }\end{array}$ \\
\hline$[68]$ & Experimental & $\begin{array}{l}39 \text { audit committee chairs - } \\
\text { members and } 42 \text { financial analysts } \\
\text { - fund managers / Australia }\end{array}$ & $\begin{array}{l}\text { Client satisfaction is related to the attributes of audit teams more } \\
\text { than those of audit firms. }\end{array}$ \\
\hline [69] & Experimental & $\begin{array}{l}600 \text { SMEs companies as listed in } \\
\text { Companies Commission / Malaysia }\end{array}$ & $\begin{array}{l}\text { Negative relationship between client satisfaction and (1) reliability, } \\
\text { (2) responsiveness, (3) assurance, (4) tangible and (5) empathy. }\end{array}$ \\
\hline [70] & Experimental & 115 Financial managers / U.S & Participation in the service exchange increases client's satisfaction. \\
\hline [71] & Experimental & 384 registered companies / Malta & $\begin{array}{l}\text { Negative relationship between client satisfaction and reliability. } \\
\text { While tangible improves client satisfaction. }\end{array}$ \\
\hline [72] & Experimental & $\begin{array}{l}80 \text { respondents from all the listed } \\
\text { companies / Jordan }\end{array}$ & $\begin{array}{l}\text { Positive relationship between client satisfaction and (1) field work } \\
\text { conduct and (2) auditor's competence. While, there is no } \\
\text { relationship between client satisfaction and experience, } \\
\text { responsiveness, independence and involvement. }\end{array}$ \\
\hline [73] & Experimental & $\begin{array}{l}60 \text { companies listed on the Nairobi } \\
\text { Securities Exchange / Kenya }\end{array}$ & $\begin{array}{l}\text { Positive relationship between customer satisfaction and (1) } \\
\text { tangibility and (2) responsiveness }\end{array}$ \\
\hline [74] & Experimental & $\begin{array}{l}94 \text { Government parastatals audited } \\
\text { by private auditors / Kenya }\end{array}$ & $\begin{array}{l}\text { Positive association between client satisfaction and (1) auditor } \\
\text { independence, (2) responsiveness and (3) technical competence. }\end{array}$ \\
\hline [75] & Experimental & $\begin{array}{l}\text { All the public and private } \\
\text { companies and state-owned } \\
\text { organizations / Botswana }\end{array}$ & $\begin{array}{l}\text { Positive relationship between client satisfaction and (1) audit firm's } \\
\text { independence; (2) audit team's industry expertise and ( } 3 \text { ) } \\
\text { interaction with audit committee. }\end{array}$ \\
\hline [76] & Archival & $\begin{array}{l}\text { One company and one certification } \\
\text { body for external auditing / U.K }\end{array}$ & $\begin{array}{l}\text { Contextual factors and factors related to the audit process influence } \\
\text { client satisfaction. }\end{array}$ \\
\hline [77] & Experimental & $\begin{array}{l}65 \text { listed venture capital firms / } \\
\text { Malaysia }\end{array}$ & $\begin{array}{l}\text { Among the } 5 \text { dimensions studied, the elements that satisfy the } \\
\text { clients are the tangibility and the reactivity of the audit. }\end{array}$ \\
\hline$[78]$ & Experimental & $\begin{array}{l}318 \text { BKM UPK that conducts - } \\
\text { implements Independent Audit / } \\
\text { Indonesia }\end{array}$ & $\begin{array}{l}\text { Client satisfaction depends on the following elements: } \\
\text { understanding of the client's industry, independence, involvement } \\
\text { of the manager and the audit committee, and compliance with } \\
\text { ethical standards. }\end{array}$ \\
\hline [79] & Experimental & $\begin{array}{l}70 \text { responds from Small and } \\
\text { Medium Enterprises / Malaysia }\end{array}$ & Auditor's competence improves client satisfaction. \\
\hline
\end{tabular}


Little research has correlated audit quality with client satisfaction, and it focused on the audit team and audit firm attributes that are relevant to auditee satisfaction. In general, the attributes most studied are:

1. Prior experience: The auditor's experience with the client.

2. Industry expertise: The auditor's knowledge of the risks, practices and standards related to the client's industry;

3. Responsiveness: The auditor's response to the client's needs;

4. Technical Competence: The auditor's technical ability to assist the client in minimizing risk and creating value;

5. Compliance with general audit standards: The auditor's adherence to current standards of practice;

6. Conduct of audit field work: Audit firms that perform audit field work are likely to provide a high quality audit;

7. Empathy: The degree of auditors' understanding of the client's business challenges;

8. Audit tangibility: The appearance of staff and physical facilities.

Behn et al. [80] were the first to conduct a study that linked audit attributes to client satisfaction. Their study of Controllers of Fortune 1000 companies found a positive association between client satisfaction and (1) responsiveness to client needs, (2) executive involvement, (3) ongoing interaction with the audit committee, (4) appropriate conduct of field work, (5) quality of commitment, (6) industry expertise and prior audit team, (7) firm experience with the client and (8) changing auditors.

Subsequently, several studies were conducted in many countries. The post-2012 studies are presented in the table 5.

The results of this research show mixed results but still offer a consensus on the impact of audit quality attributes in improving client satisfaction, and consequently audit quality. In addition, team characteristics were rated more important than audit firm characteristics.

The audit quality attributes that had the greatest impact on client satisfaction are: Responsiveness to client needs; Auditor independence; Field work conduct; Technical competence; Audit tangibility and prior experience.

\section{Audit Quality Attributes and auditor litigation}

Auditor litigation is an elementary factor in measurement of audit quality, as it not only affects the reputation of the auditor or the audit firm, but also represents a significant burden that can worsen the financial condition of audit firms. Due to its importance in measuring audit quality, audit litigation has gained prominence among researchers.

As shown in table 6, the majority of research on auditor litigation has been conducted in developed countries, using archival methods, due to the availability of databases that offer the possibility of collecting data, as well as the introduction of regulatory reforms (PSLRA and SOX) [85, 90].

Studies using litigation as a dependent variable have focused on the causes and consequences of legal actions against auditors. Causes of litigation cited include: Auditor ethics [86], positive internal control opinions [87], misstatement severity [92], lack of prior experience and others. While others studies have focused on audit fees [92], market reaction [94], the impact of litigation on auditor reputation [95], auditor behavior, going concern opinions $[78,97]$ and especially audit quality. Another stream of research has focused on the decisions of jurors and judges [89].

Overall, all the research converges towards a common result, auditors being sued provide higher audit quality because they have more wealth at risk in case of litigation. Thus, the topic of audit litigation is studied, not as a consequence of poor quality audit, but rather as an upstream risk that should be sought to prevent [96]. 
Table 6. Audit Quality Attributes and auditor litigation

\begin{tabular}{|c|c|c|c|}
\hline Reference & Method & Sample & Principle results \\
\hline \multicolumn{4}{|c|}{ Causes of auditor litigation } \\
\hline [81] & Archival & $\begin{array}{c}147 \text { firms that were } \\
\text { subject to class action } \\
\text { lawsuits naming auditors / } \\
\text { U.S }\end{array}$ & $\begin{array}{l}\text { Issuing a going concern report reduces litigation risk in general, but } \\
\text { increases litigation risk when it is issued for financially stressed clients. }\end{array}$ \\
\hline$[82]$ & Archival & $\begin{array}{c}1169 \text { observations of } \\
\text { financial reporting } \\
\text { lawsuits / Several } \\
\text { countries }\end{array}$ & $\begin{array}{l}\text { Revenue restatements have a negative and severe effect in the context } \\
\text { of litigation. }\end{array}$ \\
\hline$[83]$ & Experimental & $\begin{array}{l}20 \text { audit firms (156 } \\
\text { respondents) / Nigeria }\end{array}$ & $\begin{array}{l}\text { Positive relationship between litigation risk and audit fee, audit } \\
\text { independence; However, an insignificant relationship between } \\
\text { litigation risk and audit firm size, audit tenure and non-audit fees. }\end{array}$ \\
\hline$[84]$ & Experimental & $\begin{array}{c}442 \text { participants via } \\
\text { Amazon Mechanical Turk } \\
\text { / U.S }\end{array}$ & $\begin{array}{l}\text { There is a high risk of auditor litigation when auditors make judgments } \\
\text { that follow explicit encouragement from regulators. }\end{array}$ \\
\hline$[85]$ & Archival & $\begin{array}{l}2503 \text { class action lawsuits } \\
\text { / U.S }\end{array}$ & Reforms of both PSLRA and SOX have reduced auditor litigation. \\
\hline [86] & Experimental & $\begin{array}{l}220 \text { auditors who work in } \\
\text { the Public Accounting } \\
\text { Firm / Indonesia }\end{array}$ & Negative relationship between auditor litigation and auditor ethics. \\
\hline [87] & Archival & $\begin{array}{l}605 \text { associated with } \\
\text { restatements Internal } \\
\text { Control Weaknesses / U.S }\end{array}$ & $\begin{array}{l}\text { Negative relationship between the issuance of an adverse audit opinion } \\
\text { on internal control and auditor litigation. }\end{array}$ \\
\hline$[88]$ & Archival & $\begin{array}{c}180 \text { firm-year } \\
\text { observations / Korea }\end{array}$ & $\begin{array}{l}\text { Positive association between auditor litigation risk and operating losses } \\
\text { and high revenue growth. }\end{array}$ \\
\hline [89] & Archival & 55340 observations / U.S & No evidence of an impact of judge ideology on auditors' litigation risk. \\
\hline$[90]$ & Archival & $\begin{array}{c}\text { Federal securities } \\
\text { class-action lawsuits } \\
\text { brought against auditors / } \\
\text { U.S }\end{array}$ & $\begin{array}{l}\text { Diminution of the litigation risk under the article } 10(\mathrm{~b}) \text { (an anti-fraud } \\
\text { provision). Also, researchers found a positive relationship between } \\
\text { increased liability and improved audit quality. }\end{array}$ \\
\hline \multicolumn{4}{|c|}{ Consequences of auditor litigation } \\
\hline [91] & Archival & $\begin{array}{l}401 \text { companies listed on } \\
\text { TWSE and GTSM / } \\
\text { Taiwan }\end{array}$ & $\begin{array}{l}\text { In an environment with a low risk of litigation, a high degree of } \\
\text { dependence of an auditor on the client does not lead to accounting } \\
\text { conservatism of the audited client. }\end{array}$ \\
\hline [92] & Archival & $\begin{array}{c}\text { Studies on determinants } \\
\text { and consequences of } \\
\text { securities class action } \\
\text { lawsuits / Several } \\
\text { countries } \\
\end{array}$ & $\begin{array}{l}\text { One of the main reasons for lawsuits against auditors is poor quality } \\
\text { financial reporting. These lawsuits affect audit fees, audit planning } \\
\text { decisions and client portfolio adjustment decisions. }\end{array}$ \\
\hline [93] & Archival & $\begin{array}{l}933 \text { lawsuit cases against } \\
\text { auditors / U.S }\end{array}$ & $\begin{array}{l}\text { After auditor litigation, auditors tend to increase audit efforts and } \\
\text { charge higher fees. }\end{array}$ \\
\hline [94] & Archival & 301 litigation firms / U.S & $\begin{array}{l}\text { When the auditor is also sued, investors do not react to the } \\
\text { announcement of securities litigation against the client company. }\end{array}$ \\
\hline$[95]$ & Experimental & $\begin{array}{l}8 \text { listed companies audited } \\
\text { by the Big Four / Nigeria }\end{array}$ & $\begin{array}{l}\text { Significant effect of audit litigation on auditors' reputation and adverse } \\
\text { effect on pricing of audit services. }\end{array}$ \\
\hline [96] & Archival & $\begin{array}{c}445 \text { savings bank } \\
\text { observations / Korea }\end{array}$ & $\begin{array}{l}\text { An increase in litigation risk does not systematically increase the audit } \\
\text { quality. Also, Big N firms tend to reject riskier clients. }\end{array}$ \\
\hline$[97]$ & Archival & $\begin{array}{l}10006 \text { auditor litigation / } \\
\text { U.S }\end{array}$ & $\begin{array}{l}\text { When analyzing audit firms in the same industry and after auditor } \\
\text { litigation, audit fees and going concern opinions are more likely to } \\
\text { increase. }\end{array}$ \\
\hline
\end{tabular}

\section{- Audit Quality Attributes and Expectation-Gap}

The external auditor is an independent professional whose role is to guarantee the reliability of a company's financial communication to the stakeholders (investors, company management, employees, lenders, suppliers and others). As a result, there are many possible users of financial statements who have different expectations that cause an "Audit expectation gap", which is the difference between what auditors actually do and what third parties think auditors do or should do when conducting the audit practice [98].

Several researches have therefore taken an interest in the audit expectation gap and highlighted its existence in several developed and developing countries: Germany [99]; Romania [100]; Netherlands [30]; Nigeria [101] and others. 
Table 7. Audit Quality Attributes and Expectation-Gap.

\begin{tabular}{|c|c|c|c|}
\hline Reference & Method & Sample & Principle results \\
\hline \multicolumn{4}{|c|}{ Audit expectation gap factors } \\
\hline$[102]$ & Experimental & 110 audit firms / Kenya & $\begin{array}{l}\text { Positive relationship between the audit expectation gap and (1) } \\
\text { auditor's effort and competence; (2) user needs. }\end{array}$ \\
\hline [99] & Experimental & $\begin{array}{c}1628 \text { Auditors, } 2100 \\
\text { External groups, } 2068 \\
\text { Internal groups / Germany } \\
\end{array}$ & $\begin{array}{l}\text { Due to social aspects and recurring changes in accounting } \\
\text { requirements, the audit expectation gap is a persistent phenomenon. }\end{array}$ \\
\hline [103] & Experimental & $\begin{array}{l}30 \text { pairs of bankers from } \\
\text { several local banks and } \\
\text { accountant educators from } \\
\text { several universities / } \\
\text { Indonesia } \\
\end{array}$ & $\begin{array}{l}\text { To make investment decisions, bankers are interested in the auditor's } \\
\text { responsibilities for detecting fraud and material misstatement. }\end{array}$ \\
\hline$[104]$ & Experimental & $\begin{array}{l}50 \text { auditors, } 50 \text { bankers } \\
\text { and } 50 \text { students of the ICA } \\
\text { / Ghana }\end{array}$ & $\begin{array}{l}\text { Factors contributing to the audit expectation gap include a lack of } \\
\text { awareness about auditor's responsibilities (fraud detection and } \\
\text { prevention as well as judgment in the selection of audit procedures) and } \\
\text { the strength of the internal control structure. }\end{array}$ \\
\hline [105] & Experimental & $\begin{array}{l}190 \text { Auditors, } 193 \text { audited } \\
\text { and } 127 \text { audit users / } \\
\text { Hungary }\end{array}$ & $\begin{array}{l}\text { Factors of the audit expectation gap include: (1) Failure of the auditor's } \\
\text { performance; (2) deficiencies in auditing standards; and (3) lack of } \\
\text { interpretation of audit functions. }\end{array}$ \\
\hline$[106]$ & Experimental & $\begin{array}{l}78 \text { Accounting academics, } \\
77 \text { accounting } \\
\text { practitioners, and } 74 \text { users } \\
\text { of financial statements / } \\
\text { U.S }\end{array}$ & $\begin{array}{l}\text { Existence of the audit expectation gap between financial statement } \\
\text { users and accounting practitioners on the one hand and accounting } \\
\text { academics and financial statement users on the other. }\end{array}$ \\
\hline [107] & Experimental & $\begin{array}{c}145 \text { Auditors, } 320 \\
\text { Auditees, } 238 \text { Financial } \\
\text { communities and } 285 \\
\text { non-financial } \\
\text { communities / Libya } \\
\end{array}$ & $\begin{array}{l}\text { The audit expectation gap is mainly due to: Insufficient standards and } \\
\text { ignorance of the auditor's responsibilities and roles. }\end{array}$ \\
\hline [108] & Experimental & $\begin{array}{l}327 \text { Certified auditors / } \\
\text { Jordan }\end{array}$ & $\begin{array}{l}\text { Lack of users' awareness of financial statements increase the audit } \\
\text { expectation gap }\end{array}$ \\
\hline [109] & Experimental & $\begin{array}{l}738 \text { Shareholders and } \\
\text { directors of listed } \\
\text { companies / Pakistan }\end{array}$ & $\begin{array}{l}\text { The audit expectation gap arises primarily from the stakeholders' lack } \\
\text { of understanding of the auditor responsibilities for detecting errors and } \\
\text { frauds and detecting illegal acts. }\end{array}$ \\
\hline$[110]$ & Experimental & Public sector / Bahrain & $\begin{array}{l}\text { The factors of the audit expectation gap are: Auditors' efforts and skills, } \\
\text { users' knowledge about the audit profession and their needs. }\end{array}$ \\
\hline$[101]$ & Experimental & $\begin{array}{l}\text { Academics, accountants, } \\
\text { investors, stockbrokers } \\
\text { and bankers / Nigeria }\end{array}$ & $\begin{array}{l}\text { Lack of understanding of auditor responsibilities, especially in the } \\
\text { prevention and detection of fraud. }\end{array}$ \\
\hline [111] & Experimental & $\begin{array}{l}88 \text { Auditors, } 83 \text { financial } \\
\text { statements' preparers, and } \\
90 \text { financial statements } \\
\text { users / Saudi Arabia }\end{array}$ & $\begin{array}{l}\text { The audit expectation gap stems mainly from a lack of understanding of } \\
\text { the auditors' responsibilities, especially with regard to fraud detection. }\end{array}$ \\
\hline [112] & Experimental & $\begin{array}{c}33 \text { Auditors, } 42 \text { Investors, } \\
36 \text { Investment Analysts, } \\
35 \text { Credit Analysts, } 28 \\
\text { Regulatory Agencies / } \\
\text { Bangladesh } \\
\end{array}$ & $\begin{array}{l}\text { The audit expectation gap exists in auditor's role in: (1) Fraud } \\
\text { detection, (2) Providing non-audit services; (3) The meaning and } \\
\text { usefulness of the auditor's report; (4) Going concern reporting } \\
\text { assessment. }\end{array}$ \\
\hline \multicolumn{4}{|c|}{ Audit expectation gap reduction factors } \\
\hline [113] & Experimental & $\begin{array}{l}320 \text { Bank loan officers / } \\
\text { Malaysia }\end{array}$ & $\begin{array}{l}\text { Negative impact of the audit expectation gap on the loan decision } \\
\text { quality. And to mitigate this negative impact, the auditor must have } \\
\text { sufficient knowledge and experience. }\end{array}$ \\
\hline [114] & Experimental & $\begin{array}{l}92 \text { Auditors, } 30 \text { Banks, } \\
\text { and } 29 \text { securities } \\
\text { investment trusts / Turkey }\end{array}$ & $\begin{array}{l}\text { Audit education and the auditors' experience help to reduce the audit } \\
\text { expectation gap. }\end{array}$ \\
\hline$[30]$ & Experimental & $\begin{array}{l}61 \text { Bankers, } 118 \text { Preparers } \\
\text { and } 123 \text { Auditors / } \\
\text { Netherlands }\end{array}$ & $\begin{array}{l}\text { Clarification of the audit process and information about the going } \\
\text { concern reduces the audit expectation gap. }\end{array}$ \\
\hline$[100]$ & Experimental & 438 students / Romania & $\begin{array}{l}\text { Positive relationship between audit education and the reduction of the } \\
\text { audit reasonableness gap. }\end{array}$ \\
\hline
\end{tabular}


According to these studies, shown at table 7, there are three main factors that may effect on the audit expectation gap:

1. The auditor's ability and effort to detect fraud;

2. Nature and meaning of audit report information's;

3. Early warning by auditors of corporate failure.

And, the factors that have a significant effect on reducing the audit expectation gap are:

1. Audit education;

2. Meaningful standards;

3. Experience of the auditor.

On the other hand, there is evidence that the audit expectation gap is a persistent phenomenon as international audit standards and accounting practices improve over the years [97].

\section{Conclusions and Suggestions}

Since Deangelo's [4] famous article in 1981, research on audit quality and its main indicators has undergone a remarkable evolution, and is one of the most sought-after topics in audit.

On this basis, the purpose of our paper is to form a synthesis of the dominant research on output indicators of audit quality. By presenting a research framework that brings together the main indicators of audit quality. We review the main research on the output indicators.

First, we provide, at the level of the first section, the main definitions cited by regulators and researchers. We concluded that "Audit quality is an audit mission performed by a competent, independent, and experienced professional, in accordance with generally accepted auditing standards, to provide financial statements' users with reasonable assurance, in the auditor's report, that the financial statements and related information are presented in accordance with auditing standards and are not materially misstated."

Then, we reviewed a total of 89 studies and publications authored post-2012, which relates to outputs indicators that indicate the level of audit quality through five indicators: auditor's report, bankruptcy, client satisfaction, auditor litigation and expectation-gap.

By analyzing research on the relationship between the audit report and audit quality, we conclude that all research indicate that the audit report is not very informative and suggests in the majority cases that the audit report should contain: an opinion on going concern; detailed information on the process used by the auditor; Communication of critical/key audit matters and audit engagement partners' names.

Research on the relationship between audit quality and bankruptcy can be divided into three blocks. (1) A stream of research that studies the impact of bankruptcy on the behavior and type of auditor's opinions. They have found that the auditor becomes more conservative after bankruptcy and increasingly issues going concern modifications. (2) Another line of research focuses on the elements that can predict bankruptcy, the most important of which is the auditors' opinion on going concern, while others have found no relationship between the issuance of a going concern opinion and the bankruptcy of a firm. (3) And thirdly, research that has focused on bankruptcy prediction models, such as the model based on the analysis of traditional financial ratios, the data mining model and artificial intelligence.

The third indicator concerns client-satisfaction. Through experimental studies, researchers reported the elements that can satisfy clients on the audit work. These elements concerned, for example: Responsiveness to client needs; Auditor independence; Field work conduct; Technical competence; Audit tangibility and prior experience.

Studies on auditor litigation have focused on the causes and consequences of legal actions against auditors. Causes of litigation cited include: Misstatement severity; Auditor ethics; Positive internal control opinions; Lack of prior experience and others. While others have focused on the impact of litigation on auditor reputation, market reaction, auditor behavior, audit fees, going concern opinions and especially audit quality. Another stream of research has focused on the decisions of jurors and judges. Overall, all the research converges towards a common result, auditors being sued provide higher audit quality because they have more wealth at risk in case of litigation.

Finally, we considered that the analysis of the factors behind the audit expectation-gap is essential since it can provide information on the measures indicating the level of audit quality. The common cause of expectation-gap between countries is the misperception of the auditors' responsibility to detect and prevent fraud.

The audit quality has given rise to a great deal of research; admittedly, there are still lines researches that need to be explored.

Firstly, as we are only interested in research on output indicators of audit quality, it is therefore appropriate to conduct a literature review on input elements and the audit process. Secondly, we note that studies are much more common in developed countries. Experiences from developing countries will enrich the debate on the determinants of audit quality. Thirdly, research on the determinant client satisfaction and audit expectation gap has largely adopted the experimental method using surveys as opposed to bankruptcy research which has used the archival method. The adoption of new methods can bring and enrich the results.

\section{REFERENCES}

[1] IAASB, "Enhancing the Value of Auditor Reporting: 
Exploring Options for Change" New York, NY: International Auditing and Assurance Standards Board, 2013.

[2] IAASB, “A framework for audit quality: Key elements that create an environment for audit quality". New York, NY: International Auditing and Assurance Standards Board, 2014.

[3] PCAOB, "Concept release on audit quality indicators." New York, NY: Public Company Accounting Oversight Board, 2015.

[4] DeAngelo L. E., "Auditor size and audit quality,” Journal of accounting and economics, vol. 3, no. 3, pp. 183-199, 1981. DOI: $10.1016 / 0165-4101(81) 90002-1$

[5] Francis J. R., "A framework for understanding and researching audit quality," Auditing: A journal of practice \& theory, vol. 30, no. 2, pp. 125-152, 2011. DOI:10.2308/ajpt-50006

[6] Knechel W. R., Krishnan G. V., Pevzner M., Shefchik L. B., Velury U. K., "Audit quality: Insights from the academic literature," Auditing: A Journal of Practice \& Theory, vol. 32, no. sp1, pp. 385-421, 2012. DOI: 10.2308/ajpt-50350

[7] Chihi $\mathrm{H}$, “Contribution à l'étude de la qualité de l'audit légal: évaluation de la pertinence des spécificités réglementaires françaises," Doctoral dissertation, Paris: Paris Dauphine University.

[8] FRC, "Promoting audit quality". London: Financial Reporting Council, 2006

[9] DeFond M., Zhang J., "A review of archival auditing research," Journal of accounting and economics, vol. 58, no. 2-3, pp. 275-326, 2014. DOI: 10.1016/j.jacceco.2014.09.0 02

[10] Palmrose Z. V., "An analysis of auditor litigation and audit service quality," Accounting review, vol. 63, no. 1, pp. 55-73, 1988. https://www.jstor.org/stable/247679

[11] GAO, "Public Accounting Firms: Required Study on the Potential Effects of Mandatory Audit Firm Rotation No. 04-216". Washington, D.C.: Government Accountability Office, 2003

[12] Salehi, M., Azary, Z., "Fraud detection and audit expectation gap: Empirical evidence from Iranian bankers," International Journal of Business and Management, vol. 3, no. 10 , pp. $65-77,2008$. DOI:10.5539/ijbm.v3n10p65

[13] Arens A. A., Elder R. J., Mark B., "Auditing and assurance services: an integrated approach," Boston: Prentice Hall, 2012.

[14] Vaicekauskas D., and Mackevičius J., "Developing a framework for audit quality management in audit firms," Zeszyty Teoretyczne Rachunkowosci, vol. 75, no. 131, 2014. DOI: $10.5604 / 16414381.1098806$

[15] Kitchenham B., Brereton O. P., Budgen D., Turner M., Bailey J., Linkman S., "Systematic literature reviews in software engineering-a systematic literature review," Information and software technology, vol. 51, no. 1, pp. 7-15, 2009. DOI: 10.1016/j.infsof.2008.09.009

[16] Kitchenham B., "Procedures for performing systematic reviews," Keele, UK, Keele University, vol. 33, pp. 1-26, 2004.
[17] Xiao Y., Watson, M., "Guidance on conducting a systematic literature review," Journal of Planning Education and Research, vol. 39, no. 1, pp. 93-112, 2019. DOI: $10.1177 / 0739456 \times 17723971$

[18] International Organization of Securities Commissions, "Auditor Communications", Consultation Report, September (Madrid: IOSCO), 2009.

[19] Gul F. A., Wu D., Yang Z., "Do individual auditors affect audit quality? Evidence from archival data," The Accounting Review, vol. 88, no. 6, pp. 1993-2023, 2013. DOI: $10.2308 /$ accr-50536

[20] Carcello J. V., Li C., "Costs and benefits of requiring an engagement partner signature: Recent experience in the United Kingdom," The Accounting Review, vol. 88, no. 5, pp. 1511-1546, 2013. DOI: 10.2308/accr-50450

[21] Blay A. D., Notbohm M., Schelleman C., Valencia A., "Audit quality effects of an individual audit engagement partner signature mandate," International Journal of Auditing, vol. 18, no. 3, pp. 172-192, 2014. DOI: 10.1111/ijau. 12022

[22] Brown V. L., Gissel J. L., Vitalis A., "Mandatory Disclosure of Audit Engagement Partners: Insights from Practice," 2019. http://dx.doi.org/10.2139/ssrn.2831730

[23] Dao M., Xu H., Liu L., "Impact of the disclosure of audit engagement partners on audit quality: Evidence from the USA," International Journal of Auditing, vol. 23, no. 1, pp. 112-124, 2019. DOI: 10.1111/ijau.12149

[24] Simnett R., Huggins A., "Enhancing the auditor's report: to what extent is there support for the IAASB's proposed changes?," Accounting Horizons, vol. 28, no. 4, pp. 719-747, 2014. DOI: 10.2308/acch-50791

[25] Christensen B. E., Glover S. M., Wolfe C. J., "Do critical audit matter paragraphs in the audit report change nonprofessional investors' decision to invest?," Auditing: A Journal of Practice \& Theory, vol. 33, no. 4, pp. 71-93, 2014. DOI: 10.2308/ajpt-50793

[26] Carver B. T., Trinkle B. S. (2017). "Nonprofessional Investors' Reactions to the PCAOB's Proposed Changes to the Standard Audit Report," http://dx.doi.org/10.2139/ssrn. 2930375

[27] Mock T. J., Bédard J., Coram P. J., Davis S. M., Espahbodi R., Warne R. C., "The audit reporting model: Current research synthesis and implications," Auditing: A Journal of Practice \& Theory, vol. 32, no. sp1, pp. 323-351, 2013. DOI: 10.2308/ajpt-50294

[28] Sirois L. P., Bédard J., Bera P., "The informational value of key audit matters in the auditor's report: Evidence from an eye-tracking study," Accounting Horizons, vol. 32, no. 2, pp. 141-162, 2018. DOI: $10.2308 /$ acch-52047

[29] Köhler A., Ratzinger-Sakel N., Theis J., "The effects of key audit matters on the auditor's report's communicative value: Experimental evidence from investment professionals and non-professional investors," Accounting in Europe, vol. 17, no. 2 , pp. $105-128,2020$. DOI: $10.1080 / 17449480.2020 .17$ 26420

[30] Litjens R., van Buuren J., Vergoossen R., "Addressing Information Needs to Reduce the Audit Expectation Gap: 
Evidence from Dutch Bankers, Audited Companies and Auditors," International Journal of Auditing, vol. 19, no. 3, pp. 267-281, 2015. DOI: 10.1111/ijau. 12042

[31] Bédard J., Coram P., Espahbodi R., Mock T. J., "Does recent academic research support changes to audit reporting standards?," Accounting Horizons, vol. 30, no. 2, pp. 255-275, 2016. DOI: 10.2308/acch-51397

[32] Lennox C. S., Schmidt J. J., Thompson A., "Is the expanded model of audit reporting informative to investors? Evidence from the UK," 2018. DOI:10.2139/ssrn.2619785

[33] Bédard J., Gonthier-Besacier N., Schatt A., "Consequences of expanded audit reports: Evidence from the justifications of assessments in France," Auditing: A Journal of Practice \& Theory, vol. 38, no. 3, pp. 23-45, 2018. DOI: 10.2308/ajpt-52339

[34] Gutierrez E., Minutti-Meza M., Tatum K. W., Vulcheva M., "Consequences of adopting an expanded auditor's report in the United Kingdom," Review of Accounting Studies, vol. 23 , no. 4, pp. 1543-1587, 2018. DOI: $10.1007 / \mathrm{s} 11142-018-$ 9464-0

[35] Li H., Hay D., Lau D., "Assessing the impact of the new auditor's report," Pacific Accounting Review, vol. 31, no. 1, pp. 110-132, 2019. DOI: 10.1108/PAR-02-2018-0011

[36] Reid L. C., Carcello J. V., Li C., Neal T. L., Francis J. R., "Impact of auditor report changes on financial reporting quality and audit costs: Evidence from the United Kingdom," Contemporary Accounting Research, vol. 36, no. 3, pp. 1501-1539, 2019. DOI: 10.1111/1911-3846.12486

[37] PCAOB, "Improving the Transparency of Audits: Proposed Amendments to PCAOB Auditing Standards to Provide Disclosure in the Auditor's Report of Certain Participants in the Audit No. 2013-,009”. New York, NY: Public Company Accounting Oversight Board, 2013

[38] FRC, "International Standard on Auditing (UK and Ireland) 700. The Independent Auditor's Report on Financial Statements". London: Financial Reporting Council, 2014

[39] Svanberg J., Öhman P., "Lost revenues associated with going concern modified opinions in the Swedish audit market," Journal of Applied Accounting Research, vol. 15, no. 2, pp. 197-214, 2014. DOI: 10.1108/JAAR-11-2012-00 77

[40] Van Peursem K., Chan Y. C., "Forecasting New Zealand Corporate Failures 2001-10: Opportunity Lost?," Australian Accounting Review, vol. 24, no. 3, pp. 276-288, 2014. DOI: $10.1111 /$ auar.12029

[41] Kausar A., Taffler R. J., Tan C. E., "Legal regimes and investor response to the auditor's going-concern opinion," Journal of Accounting, Auditing \& Finance, vol. 32, no. 1, pp. 40-72, 2017. DOI: $10.1177 / 0148558 X 15602390$

[42] Izquierdo N. M., "The impact of auditing on financial distress prediction". Doctoral dissertation, Complutense University of Madrid. 2017

[43] Ittonen K., Tronnes P. C., Wong L., "Substantial doubt and the entropy of auditors' going concern modifications," Journal of Contemporary Accounting \& Economics, vol. 13, no. 2, pp. 134-147, 2017. DOI: 10.1016/j.jcae.2017.05.005

[44] Myers L. A., Shipman J. E., Swanquist Q. T., Whited R. L.,
"Measuring the market response to going concern modifications: The importance of disclosure timing," Review of Accounting Studies, vol. 23, no. 4, pp. 1512-1542, 2018. DOI: 10.1007/s11142-018-9459-x

[45] Read W. J., Yezegel A., "Going-concern opinion decisions on bankrupt clients: Evidence of long-lasting auditor conservatism?," Advances in Accounting, vol. 40, pp. 20-26, 2018. DOI: 10.1016/j.adiac.2017.12.004

[46] Caserio C., Panaro D., Trucco S., "A statistical analysis of reliability of audit opinions as bankruptcy predictors," Journal of Modern Accounting and Auditing, vol. 10, no. 9, pp. 917-931, 2014.

[47] Muñoz-Izquierdo N., Camacho - Miñano M. D. M., Pascual - Ezama D., "The content of the audit report in the year prior to bankruptcy filing. Empirical evidence from Spain," Spanish Journal of Finance and Accounting, vol. 46, no. 1 , pp. $92-126,2016$. DOI: 10.1080/02102412.2016.124 5886

[48] Gutierrez E., Krupa J., Minutti-Meza M., Vulcheva M., "How useful are auditors' going concern opinions as predictors of default?,”2016. DOI:10.2139/ssrn.2910604

[49] Gerakos J. J., Hahn P. R., Kovrijnykh A., Zhou F., "Prediction versus inducement and the informational efficiency of going concern opinions," Chicago Booth Research Paper No. 16-01, 2016. DOI:10.2139/ssrn.27277 71

[50] Armeanu D. Ş., Vintilă G., Gherghina Ş. C., Petrache D. C., "Approaches on correlation between board of directors and risk management in resilient economies," Sustainability, vol. 9 , no. 2 , pp. 173; 2017. DOI: 10.3390/su9020173

[51] Appiah K.O. and Amon C., "Board audit committee and corporate insolvency," Journal of Applied Accounting Research, vol. 18, no. 3, pp. 298-316, 2017. DOI: 10.1108/JAAR-03-2015-0024

[52] Cenciarelli V. G., Greco G., Allegrini M., "External audit and bankruptcy prediction," Journal of Management and Governance, vol. 22, no. 4, pp. 863-890, 2018. DOI: 10.1007/s10997-018-9406-Z

[53] Berglund N. R., "Do client bankruptcies preceded by clean audit opinions damage auditor reputation?," Contemporary Accounting Research, vol. 37, no. 3, pp. 1914-1951, 2019. DOI: $10.1111 / 1911-3846.12575$

[54] Muñoz-Izquierdo N., Camacho-Miñano M. D. M., Segovia-Vargas M. J., Pascual-Ezama D., "Is the external audit report useful for bankruptcy prediction? Evidence using artificial intelligence," International Journal of Financial Studies, vol. 7, no. 2, pp. 20, 2019. DOI: $10.3390 /$ ijfs 7020020

[55] Muñoz-Izquierdo N., Segovia-Vargas M. J., Pascual-Ezama D., "Explaining the causes of business failure using audit report disclosures," Journal of Business Research, vol. 98, pp. 403-414, 2019. DOI: 10.1016/j.jbusres.2018.07.024

[56] Garza-Gomez X., Okumura M., Salazar R. J., "Announcements of Going-Concern Problems Among Japanese Firms," Journal of Accounting and Finance, vol. 20, no. 1, 2020. DOI: 10.33423/jaf.v20i1.2740

[57] Desai V., Desai R., Kim J. W., Raghunandan K. “Are 
going - concern issues disclosed in audit reports associated with subsequent bankruptcy? Evidence from the United States," International Journal of Auditing, vol. 24, no. 1, pp. 131-144, 2020. DOI: 10.1111/ijau.12183

[58] Beaver W. H., "Financial ratios as predictors of failure," Journal of accounting research, vol. 4, pp. 71-111, 1966. DOI: $10.2307 / 2490171$

[59] Altman E. I., Ratios F., "Discriminant analysis and the prediction of corporate bankruptcy," Journal of Finance, vol. 23 , no. 4, pp. 589-609, 1968. DOI: $10.2307 / 2978933$

[60] Divsalar M., Roodsaz H., Vahdatinia F., Norouzzadeh G., Behrooz A. H., "A robust data - mining approach to bankruptcy prediction," Journal of Forecasting, vol. 31, no. 6, pp. 504-523, 2012. DOI: 10.1002/for. 1232

[61] Kotler P., "Marketing Management". 11th Edn.,P.T Index, Jakarta, 2006

[62] Yuniarti R., and Zumara W. M., "Audit quality attributes and audit client satisfaction," International Journal of Humanities and Management Sciences, vol. 1, no. 1, pp. 96-100, 2013

[63] Hoang K. J., "Audit Client Satisfaction and Engagement Profitability". Doctoral dissertation in Accounting, Alberta: University of Alberta, 2013

[64] Oyoo W. O., "The relationship between safety audit effectiveness and client satisfaction: a case study of private schools in Embakasi Constituency", Nairobi, Kenya. Doctoral dissertation, Nairobi: Strathmore University, 2013

[65] Reheul A. M., Van Caneghem T., Verbruggen S., "Auditor performance, client satisfaction and client loyalty: Evidence from Belgian non - profits," International journal of auditing, vol. 17, no. 1, pp. 19-37, 2013. DOI: 10.1111/j.1099-1123.2012.00455.x

[66] Herda D. N., Lavelle J. J., "How the auditor-client relationship affects the extent of value-added service provided to the client," Current Issues in Auditing, vol. 7, no. 1, pp. 9-14, 2013. DOI: 10.2308/ciia-50343

[67] Butcher K., Harrison G., Ross P., "Perceptions of audit service quality and auditor retention," International Journal of Auditing, vol. 17, no. 1, pp. 54-74, 2013. DOI: 10.1111/j.1099-1123.2012.00457.x

[68] Kilgore A., Harrison G., Radich R., “Audit quality: what's important to users of audit services," Managerial Auditing Journal, vol. 29, no. 9, pp. 776-799, 2014. DOI: 10.1108/MAJ-08-2014-1062

[69] Fazzarudin M. S., "Service Quality, Customer Loyalty and The Mediating Effects of Customer Satisfaction Towards Audit Firms: Perspective of Small-Medium Enterprise (Smes) Companies in Malaysia”. Doctoral dissertation, Universiti Utara Malaysia, 2014

[70] Herda D. N., Petersen M. J., Fontaine R., "Does client participation in an external audit affect their satisfaction with the audit service?," Managerial Auditing Journal, vol. 29, no. 9, pp. 818-836, 2014. DOI: 10.1108/MAJ-08-2013-0916

[71] Bonavia G., "Audit service quality, client satisfaction and client loyalty: evidence from Malta", Master's thesis, University of Malta, 2014
[72] Al Sawalqa F., "External audit services quality and client satisfaction: evidence from Jordan," Research Journal of Finance and Accounting, vol. 5, no. 12, pp. 223-236, 2014.

[73] Kalui F. M., Mbakaya J. A., “An analysis of audit quality attributes and client satisfaction for companies quoted at Nairobi Securities Exchange," Scholarly Research, vol. 1, no. 5, pp. 764-785, 2014.

[74] Kamuruchi R. M., "An assessment of the relationship between audit quality characteristics and client satisfaction perceptions in government parastatals in Kenya". Doctoral dissertation, Strathmore University, 2016

[75] Wally-Dima L., Mbekomize C. J., Tobedza G., "Assessment of Clients' Perceptions towards the Quality of Audit Services Offered by Auditing Firms in Botswana," Asian Journal of Business Management, vol. 8, no. 1, pp. 1-11, 2016. DOI: 10.19026/ajbm.8.2913

[76] Lenning J., Gremyr I., Raharjo H., "Drivers of audit client satisfaction in the external audit fieldwork". 21st QMOD conference, Cardiff, United Kingdom, Aug., 2018.

[77] Ismail A., Bakri M. H., Razak M. I. B. M., "Mediating effect of expected service relationship between audit service quality and customer satisfaction: a study of malaysian venture capital firms," International Conference on Communication, Information Technology and Youth Study (I-CITYS 2019), Melaka, Malaysia, Dec., 2019, pp. 99.

[78] Durya N. P. M. A., "Fraud confirmation, client satisfaction and client loyalty," International Journal of Contemporary Accounting, vol. 1, no. 1, pp. 39-60, 2019. DOI: 10.25105/ijca.v1i1.5184

[79] Ali Z. M., Mail R., Amirul S. M., "The mediation effect of clients "satisfaction between audit quality and auditor retention of small and medium enterprises (SMES)," International Journal of Accounting, vol. 4, no. 17, pp. 53-65, 2019.

[80] Behn Bruce K., et al., "The determinants of audit client satisfaction among clients of Big 6 firms," Accounting horizons, vol. 11, no. 1, pp. 7-24, 1997.

[81] Kaplan S. E., Williams D. D., "Do going concern audit reports protect auditors from litigation? A simultaneous equations approach," The Accounting Review, vol. 88, no. 1, pp. 199-232, 2013. DOI: 10.2308/accr-50279

[82] Demirkan S., Fuerman R. D., “Auditor litigation: Evidence that revenue restatements are determinative," Research in Accounting Regulation, vol. 26, no. 2, pp. 164-174, 2014. DOI: 10.1016/j.racreg.2014.09.006

[83] Edwin O. A., Bavy N. O., "Audit Firm Characteristics and Litigation Risk in Nigeria," NG-Journal of Social Development, vol. 417, no. 3947, pp. 1-16, 2016. DOI: $10.12816 / 0033089$

[84] Joe J., Sanderson K. A., Luippold B., "How Following Regulatory Guidance Can Increase Auditors' Litigation Risk Exposure," 2018,https://scholarspace.manoa.hawaii.e du/bitstream/10125/59364/HARC_2019_paper_213.pdf

[85] Moorthy L. K., Sarath B., "Regulation, Auditor Litigation and Settlements," 2018. DOI:10.2139/ssrn.2811460

[86] Agus A., Ghozali I., "Mediating effect of audit quality in 
relationship between auditor ethics and litigation: an empirical study," International Journal of Economics and Business Administration, vol. 7, no. 2, pp. 91- 100, 2019. https://www.um.edu.mt/library/oar/bitstream/123456789/4 4778/1/Mediating_effect_of_audit_quality_in_relationship _between_auditor_ethics_and_litigation.pdf

[87] Chen S. F., Chen K. C., "Disclosure of Internal Control Weaknesses and Auditors' Litigation Risk," 2019. http://dx.doi.org/10.2139/ssrn.3417147

[88] Kang M., Lee H. Y., Mande V., Woo Y. S., “Audit Firm Attributes and Auditor Litigation Risk," Abacus, vol. 55, no. 4, pp. 639-675, 2019. DOI: 10.1111/abac.12171

[89] Li L., Qi B., Zhang P. (2019). “The Impacts of Judge Ideology on Auditors' Litigation Risk: Evidence from Auditors' Behaviors,"

http://dx.doi.org/10.2139/ssrn.3351123

[90] Honigsberg C., Rajgopal S., Srinivasan S., "The changing landscape of auditor litigation and its implications for audit quality," Columbia Business School Research Paper No. 17-110, 2019. http://dx.doi.org/10.2139/ssrn.3074923

[91] Liao Y., Chi W., Chen Y., "Auditor economic dependence and accounting conservatism: Evidence from a low litigation risk setting," International Journal of Auditing, vol. 17, no. 2, pp. 117-137, 2013. DOI: 10.1111/j.1099-1123.2012.00460.x

[92] Habib A., Jiang H., Bhuiyan M. B. U., Islam A., "Litigation risk, financial reporting and auditing: A survey of the literature," Research in Accounting Regulation, vol. 26, no. 2, pp. 145-163, 2014. DOI: 10.1016/j.racreg.2014.09.005

[93] Ha W, "Do Auditors Change their Behavior after Litigation? -Evidence from Audit Fee and Audit Quality", Doctoral dissertation, Seoul: Seoul National University, 2016

[94] Amoah N. Y., Anderson A., Bonaparte I., Meyer K., "Auditor Litigation and the Penalties on US Client Firms after the Private Securities Litigation Reform Act," Journal of Accounting, Business and Management, vol. 25, no. 1, pp. $62-72,2018$. DOI: $10.31966 /$ jabminternational.v1i25.3 30

[95] Ofoegbu G.N. Onyema D.I., "Effect of audit litigation on pricing of audit services in selected Nigerian firms," International Journal of Development and Sustainability, vol. 7, no. 4, pp. 1503-1521, 2018.

[96] Jung N. C., Kim H. A., "The Effect of Litigation Risk Increase on Big N Auditor Exits and Audit Quality in the Korean Savings Banking Industry," Australian Accounting Review, vol. 29, no. 3, pp. 502-515, 2019. DOI: 10.1111/auar.12236

[97] Cao S., Fan Y., Narayanamoorthy G. S., Rowe S. P., "Auditor Litigation: Deterrence Implications for Non-sued Auditors," 27th Annual Conference on Financial Economics and Accounting Paper, Dec., 2019. DOI:10.2139/ssrn.3204957

[98] Porter B., "An empirical study of the audit expectation-performance gap," Accounting and business research, vol. 24, no. 93, pp. 49-68, 1993. DOI: 10.1080/00014788.1993.9729463

[99] Ruhnke K., Schmidt M., "The audit expectation gap: existence, causes, and the impact of changes," Accounting and Business research, vol. 44, no. 5, pp. 572-601, 2014. DOI: $10.1080 / 00014788.2014 .929519$

[100] Fulop M. T., Tiron-Tudor A., Cordos G. S., "Audit education role in decreasing the expectation gap," Journal of Education for Business, vol. 94, no. 5, pp. 306-313, 2019. DOI: $10.1080 / 08832323.2018 .1527752$

[101] Sule S., Yusof N. Z. M., Bahador K. M. K., "Users' Perceptions on Auditors' Responsibilities for Fraud Prevention, Detection and Audit Expectation GAP in Nigeria," Asian Journal of Economics, Business and Accounting, vol. 10, no. 1, pp. 1-10, 2019. DOI:10.9734/AJEBA/2019/46832

[102] Kamau C. G., "Determinants of audit expectation gap: Evidence from limited companies in Kenya," International Journal of Science and Research, vol. 2, no. 1, pp. 480-491, 2013.

[103] Rien A. F., "Audit expectation gap and its implication on credit decision making," International Journal of Scientific \& Technology Research, vol. 3, no. 2, pp. 250-257, 2014. DOI: https://doi.org/10.25095/mufad.396589

[104] Salifu I., Mahama M., "The evaluation of evidence of the audit expectation gap in Ghana," Research Journal of Finance and Accounting, vol. 6, no. 24, 2015. https://core.ac.uk/download/pdf/234631208.pdf

[105] Füredi-Fülöp J., "An empirical study of audit expectation gap in Hungary," Theory methodology practice: Club of economics in Miskolc, vol. 11, no. 1, pp. 37-46, 2015. DOI: 10.18096/TMP.2015.01.04

[106] DiGabriele J. A., "The expectation differences among stakeholders in the financial valuation fitness of auditors," Journal of Applied Accounting Research, vol. 17, no. 1, pp. 43-60, 2016. DOI: 10.1108/JAAR-06-2013-0043

[107] Masoud N., "An empirical study of audit expectation-performance gap: The case of Libya," Research in International Business and Finance, vol. 41, pp. 1-15, 2017. DOI: 10.1016/j.ribaf.2017.04.012

[108] Toumeh A. A., Yahya S., Siam W. Z., "Expectations gap between auditors and user of financial statements in the audit process: An auditor's perspective," Asia-Pacific Management Accounting Journal, vol. 13, no. 3, pp. 79-107, 2018. https://ir.uitm.edu.my/id/eprint/29521

[109] Hussain K., Khalid A., Ashraf A., "The Determinants of Client's Audit Expectations Gap: A Study from Pakistan," International Journal of Business and Management Invention, vol. 7, no. 8, pp. 27-34, 2018.

[110] Alawi S. A. A., Wadi R. M. A., Kukreja G., "The Determinants of Audit Expectation Gap: An Empirical Study from Kingdom of Bahrain," Accounting and Finance Research, vol. 7, no. 3, pp. 54-66, 2018. DOI: 10.5430/afr.v7n3p54

[111] Al-Dhubaibi A., “Auditors' responsibility for fraud detection: Views of auditors, preparers, and users of financial statements in Saudi Arabia," Accounting, vol. 6, no. 3, pp. 279-290, 2020. DOI: 10.5267/j.ac.2020.2.007

[112] Akther T., Xu F., "Existence of the Audit Expectation Gap and Its Impact on Stakeholders' Confidence: The 
Moderating Role of the Financial Reporting Council," International Journal of Financial Studies, vol. 8, no. 1, pp. 4, 2020. DOI: 10.3390/ijfs8010004

[113] Noghondari A. T., Foong S. Y., "Antecedents and consequences of audit expectation gap: Evidence from the banking sector in Malaysia," Managerial Auditing Journal, vol. 28, no. 5, pp. 384-406, 2013. DOI: $10.1108 / 02686901311327182$

[114] Köse Y., Erdogan S., "The audit expectations gap in Turkey," Journal of Accounting \& Finance, no. 67, pp. 193-213, 2015. 